\title{
Climate information to support wildlife management in the North Central United States
}

\author{
Heather M. Yocum ${ }^{1,2}$ (1) $\cdot$ Andrea J. Ray ${ }^{2}$ \\ Received: 9 March 2017 / Accepted: 28 January 2019 / Published online: 22 February 2019 \\ (C) Springer-Verlag GmbH Germany, part of Springer Nature 2019
}

\begin{abstract}
This paper investigates what is needed to make climate and weather information more usable for the wildlife management practitioners and ecological researchers in the Prairie Potholes Region (PPR) of the North Central United States. Using interviews, policy document analysis, and participant observation, we identify climate and weather information needs, barriers to use, and opportunities to provide better information to these users. We found that the research and management communities need guidance on how to interpret and apply existing information. Climate information needs in the PPR are driven by the need to understand how projected changes in precipitation will impact prairie wetland ecology. Primary needs include guidance towards selecting, interpreting, and using various climate information products to understand impacts and explanations of the differences between new products and previously available information. Another need includes information on how the societal responses to climate change will further impact ecological systems. Existing management priorities, limited institutional resources, and limited ecological data are remaining barriers that can be ameliorated by leveraging existing policy processes or trusted sources of information to provide guidance, thereby reducing time and costs associated with using climate information in wildlife policy planning. Throughout, we emphasize the importance of the social and ecological aspects of the decision-making context to shape climate information needs, barriers, and entry points. Additional research is needed on the diverse ways that users engage with and use climate information, and additional efforts are needed to co-produce guidance documents that interpret climate information for management and research communities.
\end{abstract}

Keywords Climate change $\cdot$ User information needs $\cdot$ Natural resource management $\cdot$ Conservation $\cdot$ Decision-making $\cdot$ Prairie potholes

Editor: Nicolas Dendoncker

Electronic supplementary material The online version of this article (https://doi.org/10.1007/s10113-019-01474-y) contains supplementary material, which is available to authorized users.

Heather M. Yocum

heather.yocum@colorado.edu

Andrea J. Ray

andrea.ray@noaa.gov

1 Cooperative Institute for Research in Environmental Sciences (CIRES), University of Colorado, Boulder, CO, USA

2 Physical Sciences Division, NOAA Earth System Research Laboratory, Boulder, CO, USA

\section{Introduction}

The Prairie Pothole Region (PPR) in the north-central Great Plains is one of the most threatened waterfowl habitats in the USA due to habitat fragmentation and degradation. How climate change will impact the ecology and hydrology of prairie grassland and wetland habitats in the PPR in the coming decades is a key question for wildlife management practitioners as they consider where to site long-term conservation actions. The importance of climate information to assess species and ecosystem vulnerability as part of comprehensive adaptation planning is welldocumented (Association of Fish and Wildlife Agencies 2012; Glick et al. 2011; Heller and Zavaleta 2009; Mawdsley et al. 2009; Stein et al. 2014; West et al. 2009). State and federal natural resource managers recognize the importance of adapting management strategies to climate change, but report that use of climate information 
is limited and that available climate information does not meet their needs (Ellenwood et al. 2012; Lemieux et al. 2013; Olliff and Hansen 2016).

As part of a larger project motivated by the urgency of the conservation issues in the PPR and the complex and sometimes conflicting information about the future climate (e.g., Ballard et al. 2014), the goal of this paper is to support the development of usable climate information for state- and regional-level personnel involved in wildlife management in the PPR and who are responsible for integrating climate change into state and regional conservation policy planning. We focus on observed and projected precipitation and temperature data presented in academic papers, reports (e.g., IPCC 2010; National Climate Assessment 2010), and climate viewers and portals (e.g., Climate Wizard, USGS Geodata Portal; Blodgett et al. 2011) that can be used to understand the implications of projected changes for habitats, species, and ecological communities. We also discuss information needs pertaining to how climate change will impact future natural variability and extremes.

There is a growing literature concerning climate and weather information needs and how to make climate and weather information more useful for natural resource managers and decisionmakers. Users often have difficulty understanding and applying available climate information products (Archie et al. 2012; Barsugli et al. 2012; Dilling and Berggren 2014; Kemp et al. 2015; Maurer et al. 2014) or understanding the interplay between old and new climate information (Lemos et al. 2012). Thus more effective communication and guidance on using climate change information is needed, including clarification on the range of possibilities, or uncertainty, in future climate projections (Dilling and Berggren 2014; Ray et al. 2018).

Natural resource managers also need climate projections on geographic and temporal scales appropriate for addressing management questions (Archie et al. 2012; Barsugli et al. 2009; Berggren 2012; Gonzalez 2011; Jantarasami et al. 2010). Additional observational data and historic datasets are needed to establish baselines against which to measure and monitor change and to conduct vulnerability assessments for adaptation planning (Berggren 2012; Glick et al. 2011; Gonzalez 2011). Users also need additional information on potential climate change impacts (Berggren 2012; Briley et al. 2015), for example, tools that link ecological processes and climate models, that provide the ecologically-relevant variables (Ray et al. 2018), or that include GIS-compatible data (Theoharides et al. 2009). To meet information needs for particular users, it is necessary to describe what credible, salient, and legitimate climate information actually means for particular users or when applied to specific management questions (Cash et al. 2002; Snover et al. 2013).

This paper contributes to the understanding of how social and ecological contexts shape climate information needs, particularly how context influences how user groups access and use (or might use) climate information. Additionally, we highlight how users' previous encounters with climate information shape both how they perceive new information and their need for guidance on selecting and applying it. We describe the climate and weather information needs for the PPR and the implications beyond the region, as for example Dilling et al. (2015) do for the western USA. We then describe the remaining barriers to using climate change information in the PPR. We conclude by discussing opportunities, or entry points (Ray and Webb 2016), for the climate science community to engage with the wildlife management community and ecological researchers to better meet these needs. First, however, we describe the social and ecological decision-making context of the PPR in order to foreground our discussion of climate information needs.

\section{Context of the prairie potholes region}

Understanding the ecological, social, and climate context in which wildlife management decisions are made in the PPR is key to understanding information needs. The PPR stretches over 300,000 $\mathrm{mi}^{2}$ in Iowa, Minnesota, South Dakota, North Dakota, and Montana and northward into Canada (Fig. 1). The wetlands and grasslands of the PPR are one of the most productive areas in the world for breeding waterfowl, and are an important habitat for a number of other species, including migratory grassland and shore birds, mule deer, pronghorn antelope, and numerous fish and amphibian species (Dyke et al. 2015; South Dakota Department of Game, Fish and Parks 2014). Between 50 and $80 \%$ of North American ducks breed in the PPR, and the number of waterfowl is closely associated with the number and quality of wetlands and surrounding grasslands, which in turn depend upon the timing, amount, and spatial distribution of precipitation (Dyke et al. 2015; Johnson et al. 2005; Ostergren 2003). The majority of the precipitation in the PPR falls in April thru July (50-60\%), coinciding with the waterfowl breeding season.

Practitioners in the wildlife management community in the PPR must deal with immediate threats to many of the species and ecosystems within their jurisdictions. These critical management issues (Ray and Webb 2016) include plowing of native prairie and expansion of corn agriculture, the rapid development of the oil and natural gas industry, and the draining or consolidation of wetlands, all of which have reduced grassland and wetland habitats at a time when federal funds to support conservation easements on private lands via the Conservation Reserve Program (CRP) are decreasing. These competing management priorities vie for limited institutional resources with longer-term issues like climate change (Archie et al. 2012; Theoharides et al. 2009). Historically characterized by tall-, mixed-, and short-grass prairie punctuated by approximately 5-8 million permanent, semi- 


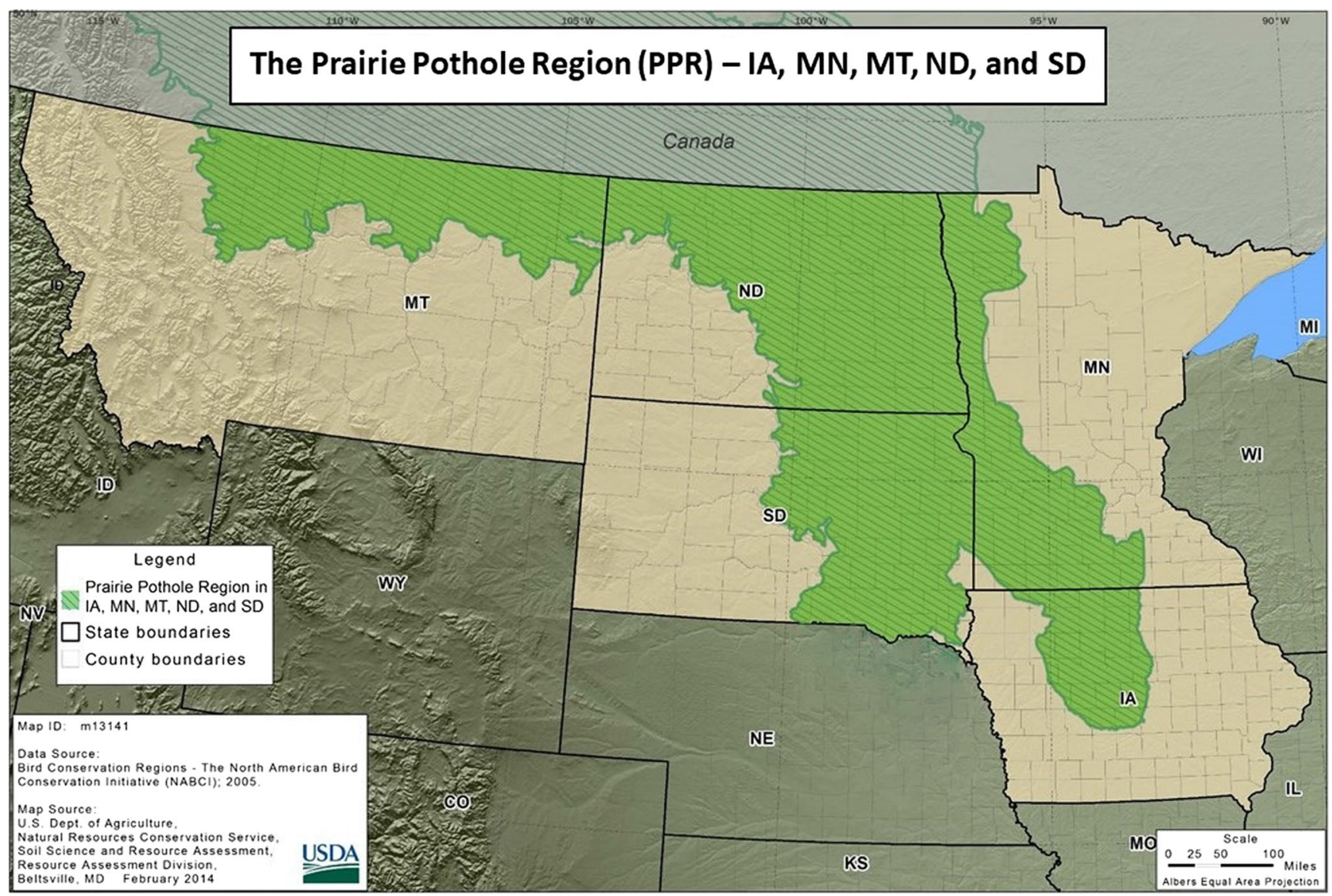

Fig. 1 Map of the Prairie Potholes Region (PPR), courtesy of the US Department of Agriculture Natural Resources Conservation Service

permanent, and seasonal wetlands, wetland loss since European settlement began in the 1870s has been significant: over $90 \%$ of wetlands in Minnesota have been drained; $89 \%$ in Iowa; $49 \%$ in North Dakota; $35 \%$ in South Dakota; and 27\% in Montana (Millett et al. 2009). These areas include some of the most productive waterfowl habitats in the region (Johnson et al. 2010). The majority of land in the PPR is owned privately, so wildlife managers must collaborate with private landowners and nonprofit organizations to conserve prairie wetlands and grasslands and meet federal and state conservation targets. Federally funded conservation easements via the CRP are revisited every $10-15$ years and are a major tool for encouraging conservation on private land (Doherty et al. 2013; Reynolds et al. 2001). Spatially explicit climate information about future impacts on the spatial distribution of wetlands and waterfowl breeding sites could help ensure that these easements are located in areas that can support waterfowl and other key species in the future.

The climate of this region is spatially and temporally complex. The PPR is characterized by an east-west precipitation gradient, being drier in the west and wetter in the east (Kunkel et al. 2013; Millett et al. 2009; Shafer et al. 2014). The region is also characterized by extremes in weather, large seasonal variability, and decadal drought and deluge cycles (Millett et al. 2009; Winter and Rosenberry 1998). These wet and dry cycles and the inter-annual variation in the seasonal period of high water levels in spring and summer - known as the hydroperiod-impact vegetation cycles in the potholes (Beeri and Phillips 2007; Johnson et al. 2005). The spatial distribution, size, and depth of the seasonal potholes in the spring and summer, and the type and quality of the surrounding grassland vegetation, affect migration patterns and the availability of food and nesting sites for waterfowl and other dependent species.

There has been an evolving understanding of the future climate of the region, how climate change will impact natural variability (Ballard et al. 2014; Kunkel et al. 2013), and the implications for grassland and wetland management (e.g., Reese and Skagen 2017; Sofaer et al. 2016). A recent wet trend beginning in the mid-1990s and lasting nearly two decades brought above-average precipitation to the PPR. This wet trend has been attributed to natural variability, but some models indicate that the overall E-W precipitation gradient may be steepening (Ballard 2014; Millett et al. 2009; Shafer et al. 2014). Understanding the management implications for these medium- and long-range changes in precipitation is key for adaptation planning. 
Understanding the social and ecological context clarifies the type and timing of climate information that would be useful for natural resource management. The complex hydroperiod of the PPR demonstrates the importance of considering the combined effects of future changes in both precipitation and evaporative demand (e.g., Ballard et al. 2014). This information is vital during the April through July waterfowl breeding season, which does not necessarily align with the traditional annual or seasonal timeframes in which climate information is often presented. Understanding this context is a necessary first step towards identifying and meeting climate information needs.

\section{Methods}

This study used key informant interviews, participant observation at two regional workshops, and policy document analysis of State Wildlife Action Plans (SWAPs) to solicit information about climate information needs, barriers to use, and potential entry points. These three data streams represent different but complementary perspectives from practitioners in the wildlife management community and ecological researchers in the PPR. The use of multiple methods, or triangulation, increases the internal validity of qualitative results by allowing for comparison between the different data streams (Bernard 2005; Reinharz 1992).

Based on initial conversations with personnel working with state and federal agencies to improve climate information provision in the region-including Landscape Conservation Cooperative staff and NOAA's Regional Climate Service Director-we narrowed our focus to identifying the climate information needs to support wildlife and habitat management in the wetlands and grasslands of the PPR. We used a purposive (intentional) sampling technique (Bernard 2005) to select 16 individuals for key informant interviews. Interviewees were selected based on their role in making state or regional wildlife management policy decisions and/or their experience using climate data to support these decisions. Interviews were conducted between July and December 2014 and consisted of nine open-ended questions with conditional prompts and follow-up questions (Online Resource 1). This approach enabled us to collect comparable data while also allowing interviewees to identify and discuss additional topics that were important to them.

The selected individuals from state and federal agencies and two non-profits are representatives of practitioners in the PPR wildlife management community. We interviewed federal agency staff from the US Fish and Wildlife Service $(n=5)$, US Forest Service $(n=1)$, US Department of Agriculture $(n=1)$, and the Environmental Protection Agency $(n=1)$, and staff from the ND
Department of Game and Fish $(n=3)$. We included personnel from two non-profit organizations involved in waterfowl conservation $(n=2)$ because they conduct conservation programs in the PPR and often cooperate with private landowners and federal and state agencies to achieve conservation goals. We also interviewed university-based biologists and ecologists $(n=3)$ about their use of climate change information in research that ultimately supports decisions, including their contributions to the SWAPs. Agency and non-profit staff were involved in state and regional decision-making, but also conducted their own biological and ecological research to support conservation efforts in the PPR.

Participant observation and policy document analysis provided a broader contextual understanding of wildlife management in the PPR. These methods bring greater depth and nuance to data collected through interviews, facilitating triangulation to add confidence in the findings (Bickman and Rog 2009). We conducted participant observation during fieldwork over several weeks in the PPR and at two strategically chosen meetings: the North Dakota Chapter of the Wildlife Society Meeting and the Connections II Workshop, a research-sharing event sponsored by the PPR Landscape Conservation Cooperative. Participant observation includes recording extensive field notes on interactions between people and groups of interest as a way to complement data collected during structured interactions with the researcher (e.g., interviews) (DeWalt and DeWalt 2002).

We analyzed the most recent SWAPs for the five states with lands in the PPR to gain a clearer understanding of regional conservation challenges and climate information needs: Iowa (Iowa Department of Natural Resources 2015), Minnesota (Minnesota Department of Natural Resources 2016), Montana (Montana Fish, Wildlife, and Parks 2015), North Dakota (Dyke et al. 2015), and South Dakota (South Dakota Department of Game, Fish and Parks 2014). State wildlife management agencies prepare these SWAPs, which identify conservation challenges and plans for conserving species and habitats. SWAPs are revised every 10 years, and the most recent revisions mandated that all states consider climate change impacts on these species and habitats. The revision process itself has multiple stages over several years, offering entry points for scientific input and public comment.

Interview transcripts, field notes, and SWAPs were analyzed using Atlas.ti software to code, or label, the text-based data. Six a priori codes were based on the interview questions, and additional codes were identified and assigned based on emergent themes that arose during data collection (Table 1). Since the data from each method complements the others, data from all three collection methods are combined and organized thematically below. 
Table 1 List of a priori and emergent codes used in analysis of textual data from interview transcripts, field notes from participant observation at meetings, and State Wildlife Action Plan documents

\begin{tabular}{|c|c|}
\hline A priori codes & Emergent themes \\
\hline $\begin{array}{l}\text { - Decision-making processes } \\
\text { - Sources of climate and weather information } \\
\text { - Uses of climate and weather information } \\
\text { - Impacts of climate change on the PPR } \\
\text { - Information needs } \\
\text { - Social factors considered in decision } \\
\text { making }\end{array}$ & $\begin{array}{l}\text { - Decision-making and decision calendars } \\
\text { - Reports and other outputs } \\
\text { - Management options and policies } \\
\text { - Data sources (e.g., institution or individual) } \\
\text { - Weather and climate data sources (e.g., global circulation } \\
\text { model) } \\
\text { - Manager terms for weather and climate data } \\
\text { - Weather and climate impacts on wildlife and ecology } \\
\text { - Habitat } \\
\text { - SGCN (species of greatest conservation need) } \\
\text { - Communication } \\
\text { - Interactions between climate scientists and users } \\
\text { - Monitoring } \\
\text { - Uncertainty } \\
\text { - Natural variability } \\
\text { - Oil and natural gas development } \\
\text { - Institutional resources, culture, and practice } \\
\text { - Networks (social and professional) }\end{array}$ \\
\hline
\end{tabular}

\section{Results}

\section{Climate and weather information needs in the Prairie Pothole Region}

We found that the driving climate change question in the wildlife management community in the PPR was "Where will the rain and water be, how much will there be, and when?" Practitioners want to understand how projected changes in precipitation and temperature will impact prairie wetland ecology, particularly as it relates to the spatial distribution of key habitats. Information needed includes spatially-explicit projected shifts in the spatial distribution of rainfall, changes in the amount of precipitation, shifts in seasonality, and how far in the future these changes are projected to occur (Yocum 2017). Interviewees are particularly interested in understanding if projected changes will shift the location of prime waterfowl breeding habitat south and east, as some studies have suggested (e.g., Johnson et al. 2005, 2010). Interviewees also want information about how climate change is expected to impact the frequency and severity of weather and climate-related events at different temporal scales, including seasonal (e.g., drought), inter-annual (e.g., El Niño Southern Oscillation or ENSO), and decadal time scales (e.g., changes in natural dry/wet cycles) whose impacts on habitats and species in the PPR are beginning to be explored.

Rather than simply more climate data, these practitioners and researchers require translational or interpretive information that includes guidance about the quality and appropriateness of use for various applications, especially projected impacts on key habitats and species. These needs are described below. Interview responses are shown in Fig. 2, and results are summarized in Table 2.

\section{Guidance}

The most cited need identified by interviewees $(n=14 ; 88 \%)$ was guidance on how to select and use climate information currently available, including guidance on the differences between different GCMs and between various downscaled products $(n=9,56 \%)$ and in discerning how precipitation will change at different time scales $(n=12,75 \%)$, particularly as it relates to the recent wet cycle and projected future changes. This is consistent with other studies which found that guidance on selecting and using climate data is one of the most commonly cited needs from user groups (e.g., Maurer et al. 2014). Although existing guidance documents compare different downscaled products (e.g., IPCC 2010; National Climate Assessment 2010; NOAA GFDL 2018; Trzaska and Schnarr 2014; Wilby et al. 2004; Wootten et al. 2014), these discussions are often not widely circulated among potential users of climate information and do not adequately interpret how non-climate experts could use this information. Interviewees expressed frustration at perceived hesitation from the climate science community to indicate which of the various scenarios, GCMs, or downscaled products might be the most appropriate for particular management questions. One interviewee explained, "Our big frustration is that a lot of climate change scientists just won't tell you one way or the other. And I understand; they 


\section{Interview Responses}

Guidance in selecting appropriate climate projections and downscaled products

Guidance to understand differences between different GCMs and between various downscaled products

Guidance to discern changes in precipitation at different timescales

Putting new information in context of the local climate knowledge canon

Guidance on differences between CMIP3 and CMIP5

Additional observational data on weather-climate-ecological relationships

Seasonal forecast (e.g., ENSO) information

Social impacts

Conflicting management priorities (e.g., rapid land use change leading to habitat fragmentation and degradation)

Lack of ecological data on species and habitats

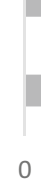

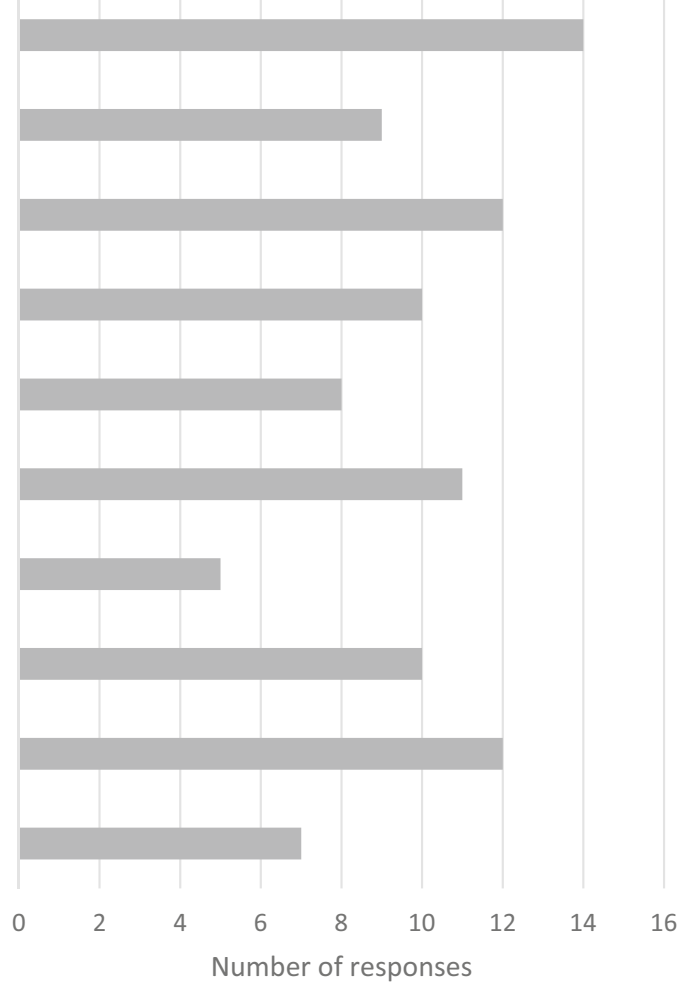

Fig. 2 Climate information needs and barriers identified during interviews

don't want to make a judgment call or anything. And so we're kind of coming from the other end where we've got a deadline, we've got a budget, and we've got to get our deliverable out ... We need to have the climate science people say 'OK, I would recommend that you use this and here is why.'"

\section{Climate information users}

Our interviews emphasized the importance of understanding the nuances of how climate information is actually being used. Climate information uses we observed include use in ecological modeling, to inform management actions, assess vulnerability or risk, or as general information to inform, e.g., in the SWAPs. This is consistent with a range of uses found by Ray and Webb (2016).

Furthermore, some interviewees could not be neatly categorized into "managers" who make decisions and "researchers" who use climate information in ecological analysis. Federal and state agency staff and non-profit personnel whom we interviewed were responsible for making state and regional wildlife management decisions, but also sometimes conducted their own research and exploratory analysis when available climate impact information did not meet their needs. One state-level wildlife manager reported using both observed and projected temperature, precipitation, and wind data to better understand impacts on game bird populations in vulnerability analyses and regional conservation decisions. Other agency staff have collaborated with university researchers to examine the impacts of ENSO patterns on deer populations to inform hunting license allocations (Ciuti et al. 2014, 2015). Understanding the nuanced ways that users engage with and use climate information is one factor which shapes climate information needs and the type of information and guidance needed to help meet them.

\section{The local climate knowledge canon}

Any guidance for using climate information needs to place new information into the context of what we call the local climate knowledge canon: key data or papers that have had significant influence in the way that particular users understand and use climate change information. Two key papers in the PPR drove many of the climate information needs voiced by our interviewees. These studies used idealized climate scenarios to force wetland models and project changes to the quality and spatial distribution of waterfowl habitat under particular temperature and precipitation changes (Johnson et al. 2005, 2010). These studies projected that the best and 
Table 2 Climate information needs, barriers to use, and entry points for climate information identified from interviews, participant observation at meetings, and policy document analysis

Climate information needs in the PPR:

Guidance in selecting appropriate climate projections and downscaled products

- Guidance to understand differences between different GCMs and between various downscaled products

- Guidance to discern changes in precipitation at different timescales

Putting new information in context of the local climate knowledge canon

Accessible guidance on differences between CMIP3 and CMIP5 and if impact models or decision-support tools based on CMIP3 are still valid

Observational data to document and correlate weather-climate-ecological relationships

- Additional monitoring sites to document weather and climate impacts on wildlife and landscapes

- Additional wetland hydrology monitoring sites

- Long-term weather station data relating to hydroperiod

Seasonal forecast information (e.g., ENSO) for possible correlation with weather-climate-ecological relationships (e.g., mule deer population)

Projected climate change impacts on social systems (e.g., land use change), and how those changes will impact ecological systems

Barriers in the PPR:

Limited institutional resources

Existing management priorities

- Land use change (e.g., conversion of land to agriculture; oil and gas development)

- Habitat loss, fragmentation, and degradation

Limited understanding of species' distribution and lifecycle which makes it difficult to evaluate vulnerability to climate change

Entry points specific to the PPR:

Meeting user needs for guidance on how to use climate information

- Synthesizing continuing advances in climate science and newly-available climate information

- Explaining conflicting results between existing and newly available information

Policy and management processes

- Endangered Species Act listing considerations

- SWAP revisions (approx. every 10 years)

- Climate vulnerability assessments

- Siting conservation easements

- Oil and natural gas permitting processes

Trusted Sources

- USFWS Habitat and Population Evaluation Team (HAPET)

- North Dakota Agricultural Weather Network (NDAWN)

most reliable waterfowl habitats would not only decrease, but also shift away from the Dakotas towards Minnesota and Iowa. These findings were incredibly problematic for the waterfowl conservation community and their efforts, since conserving existing wetlands and prairies in the Dakotas is less expensive than acquiring and restoring wetlands already converted to agriculture in Minnesota and Iowa. These papers came up in every interview with practitioners involved with regional waterfowl conservation $(n=10)$, were discussed at both meetings we attended, and were referenced multiple times in the ND and SD SWAPs. These papers spurred additional studies discussing the implications for a shift in geographic focus of waterfowl conservation activities (e.g., Niemuth et al. 2014).

Any new climate information encountered by those working in waterfowl conservation is considered against these two studies (Johnson et al. 2005, 2010), and any guidance on using climate information needs to address this climate knowledge canon. While these practitioners would like clarification on future changes in precipitation and temperature and impacts on prairie wetlands and grasslands, existing climate knowledge can be a "sticking point" which can hinder the integration of new or conflicting information into natural resource management if not properly addressed (Waylen et al. 2015). This finding supports Lemos et al.'s (2012) finding that guidance on using climate information must consider previous user experiences and the interplay of old and new climate information in order to be effective.

\section{Is CMIP3 "stale"?}

Interviewees stated the need for guidance on the evolving science of climate projections, including assistance understanding how, when, or even if new information should be used. Half of the interviewees $(n=8)$ noted concerns about a lag time to move information "down the pipeline" from the producers of GCM output into products for use in impact analysis. For example, interviewees want clarification on the differences between CMIP3 and CMIP5 projections for regional shifts in seasonality, precipitation, and temperature so they can determine if existing analyses, decision-support tools, or vulnerability assessments based on CMIP3 - e.g., NatureServe Climate Change Vulnerability Index tool (NatureServe 2018.

${ }^{1}$ ) used in SWAPs - are still valid, if they need to be updated with CMIP5 data, or if they should wait for the release of CMIP6 to update them. This finding is consistent with other studies (e.g., Maurer et al. 2014). Although studies available at the time of the interviews explored the differences between the projected impacts of CMIP3 and CMIP5 (e.g., Bureau of Reclamation 2013; Knutti and Sedláček 2013), this information appeared in technical documents and journals and had not yet reached our interviewees, reinforcing the need for more accessible guidance aimed at information users. Additionally, some CMIP3-CMIP5 comparisons (e.g., Knutti and Sedláček 2013) only examine global mean variables, which could differ for management-relevant variables on regional scales. The climate science community will need to continually provide

\footnotetext{
${ }^{1}$ Version 2.1 of the NatureServe Climate Change Vulnerability Index was available during the time that most SWAPs were undergoing revision. In 2015 , it was updated to version 3.1, cited herein.
} 
updated guidance and translational information as the science evolves, for example when CMIP6 is released.

\section{Additional observational data}

Interviewees cited the need for additional observational data in order to enhance understanding of ecosystem responses to current climate. Sixty-nine percent of interviewees $(n=11)$ identified a need for observation-based weather and climate data coupled with better ecological data to document weatherclimate-ecological relationships, a need reiterated in all five SWAPs and during both meetings we observed. In the PPR, a specific need is long-term weather data and observations related to the hydrologic variables and ecosystem response. For example, few wetland hydrology monitoring sites in the PPR have long enough data sets to identify changing trends in the measures of wetland-related variables (e.g., hydroperiod and evaporative demand) (Beeri and Phillips 2007; Johnson et al. 2004; Millett et al. 2009). Better observational data could be used to correlate and document weather-climate-ecological relationships, evaluate and further refine existing vulnerability assessments (e.g., Lawler et al. 2009), and detect climate change impacts on species and habitats (Glick et al. 2011; Gonzalez 2011) throughout the PPR.

\section{Seasonal forecast and ENSO information}

Several interviewees $(n=5,31 \%)$ made specific requests for more information about how climate change will impact the frequency and severity of weather and climate cycles such as drought, ENSO phase, and the natural variability of decadal dry/wet cycles whose impacts on habitats and species in the PPR are beginning to be studied. Wildlife biologists at universities and state agencies have collaborated to examine ENSO impacts on precipitation and temperature in the PPR to better understand weather-climate-ecological relationships, and in turn, to inform management decisions. In one study, ENSOrelated anomalies on winter and spring temperatures were correlated with white-tailed deer population numbers in southwest ND, since longer, colder winters negatively impact the health of the doe, which in turn leads to higher fawn mortality that year but lower fawn mortality in the subsequent year (Ciuti et al. 2014, 2015). Interviewees want to know the strength and reliability of the correlation between ENSO phases and temperatures in the PPR in order to use ENSO outlooks to improve estimates of deer populations and inform decisions about hunting allowances. Interviewees also reported ongoing research looking for similar patterns in pronghorn antelope and game bird populations across the PPR. However, both practitioners and researchers need to know the strength and reliability of ENSO impacts on both present and future temperatures and precipitation in the PPR before this information can be used to inform management decisions. Additional research is needed to better understand the impacts of ENSO cycles, droughts, and severe weather on species and habitats, and to understand how climate change will impact these cycles.

\section{Social impacts}

These practitioners need more information about how climate change is projected to impact social systems (e.g., land use change), and how those changes will in turn impact key species, ecological communities, and habitats. This was a major need stated in all five SWAPs and was articulated in the majority of interviews $(n=10)$ and during the workshops we attended. In the PPR, a confluence of social and economic factors combined with the recent wet trend has spurred a shift from winter wheat crop systems which are more amenable to nesting waterfowl populations, to corn and soy, which are not (Rashford et al. 2011). Complex information on interactions between climate, social, and ecological systems will require collaboration between climate scientists, impact modelers and researchers, social scientists (e.g., Wilby and Dessai 2010), and in this case, the wildlife management community across scales.

\section{Perceived barriers to using climate information}

Climate change is not the only issue that the wildlife management community is dealing with, and these additional issues are part of the decision-making context that affect the use of climate information. In the PPR, these include existing management priorities which compete for limited institutional resources and a lack of basic data on species and habitats. These perceived barriers are unrelated to the quality or availability of climate change information but nevertheless influence its use. While a full discussion of these barriers is beyond the scope of this paper, they are mentioned here to illustrate opportunities for the climate science community to reduce-though not eliminate-them.

The pressure to deal with rapid socio-economic changesparticularly land use change, the conversion of prairie and wetlands to agriculture, and oil and natural gas development - was cited as higher priority than climate change in interviews $(n=12 ; 75 \%)$ and during meetings we attended. Habitat loss, fragmentation, and degradation related to land use change were key threats to conservation identified in all five of the SWAPs. These critical management problems compete for limited institutional resources with longer-term issues like climate change (Niemuth et al. 2014; Ray and Webb 2016). One interviewee explained, "[Climate change is] not a part of the day-to-day dialogue here. It's just not. Because we're looking at losing wetlands. We're looking at losing grass. We're looking at low reproductive rates. It's hard 
to look seven chapters ahead." Another added, "Frankly, if we don't come up with the right public policy solutions now, we won't have to worry about it in 50 years, because we will have lost too much carrying capacity." Furthermore, several interviewees revealed that they felt less willing to discuss publicly the use of climate information to inform management decisions due to the politicization of climate change.

Interviewees $(n=7,44 \%)$ and all five SWAPs indicated that current understanding of many species' lifecycles is inadequate to identify the weather and climate factors impacting populations, complicating efforts to identify specific climate information needed for decision-support. For example, in ND, basic lifecycle data is available for only $120-150$ of the approximately 600 known vertebrate species in the state (Dyke et al. 2015), while the MN and SD SWAPs cited the lack of species data as a barrier to adaptation planning (Minnesota Department of Natural Resources 2016; South Dakota Department of Game, Fish and Parks 2014).

Although these barriers cannot be remedied only by delivering better climate science, the climate science community can take actions to reduce them. For example, improved communication and engagement between the climate science and wildlife management communities can decrease the time and effort required to use climate information, relieving some of the pressures related to finite institutional resources (e.g., Meadow et al. 2015). Such opportunities are discussed below.

\section{Entry points for integrating climate information}

The information needs and barriers described above can offer opportunities - or entry points (Ray and Webb 2016) - for climate scientists to engage with users of climate information. We now describe three potential entry points which can help overcome institutional constraints related to limited resources and which capitalize on synergies between the needs and barriers described above.

\section{Research synthesis and guidance as entry points}

The continuing advances in climate science and the availability of new climate change information provide the opportunity to offer needed guidance to these practitioners in the form of a synthesis of available climate science aimed at helping practitioners select appropriate climate information to address management questions. This is especially important to help reduce confusion about the seemingly conflicting results in available climate information, the differences between decision-support tools and vulnerability assessments based on CMIP3 and CMIP5, and differences between the various downscaled products and available guidance documents. The local climate knowledge canon also needs to be considered in any guidance or synthesis offered by the climate science community.
As presented above, we found that $75 \%$ of the interviewees cited concerns over changes in precipitation occurring at different time scales, particularly pertaining to the recent wet trend occurring in the PPR since the late 1990s, if these changes are caused by climate change, and projected impacts on the natural variability of wet and dry cycles. Confusion about future changes in climate and precipitation that we observed in interviews may stem from the following: (1) studies reporting information about projected temperature and precipitation changes (Kunkel et al. 2013) but not necessarily showing the combined effects of these changes (e.g., evapotranspiration in Ballard et al. 2014); (2) language describing "drying" and "wetting" or wetter conditions that in some cases refers to changes in precipitation and in others refers to variables that respond to a combination of the effects of increased precipitation and increased temperature (e.g., the Palmer Drought Severity Index in Ballard et al. 2014; wetland cover cycle in Johnson et al. 2005); and (3) products based on different climatological periods, generations of GCMs, or which use different downscaling techniques (Ballard et al. 2014; Kunkel et al. 2013).

To overcome this confusion, climate scientists should provide a synthesis of research findings regarding the evolution of scientific understanding of projected climate changes and, when possible, projected impacts on weather-climateecological relationships in the PPR. A brief example will demonstrate the complex and sometimes conflicting information that this type of synthesis could help clarify. In the National Climate Assessment, Figs. 24-25 in Kunkel et al. (2013) show increases in the ensemble mean for projected temperature and precipitation across the PPR for both the annual average and for all seasons. However, other studies have found that increasing temperatures mean that precipitation increases are likely to be at least partially offset by higher evaporative demand (Ballard et al. 2014; Cook et al. 2014). Furthermore, the recent wet trend is most likely primarily due to natural variability: only about half of the trend in precipitation can be attributed to radiative forcing (or anthropogenic climate change) and this effect is only in the spring; there is little effect in other seasons (Ballard et al. 2014). A synthesis of this (and other key references beyond the scope of this discussion) could point out that the differences may be due to the use of two generations of CMIP GCMs (Kunkel et al. 2013 used CMIP3, the other two used CMIP5). The use of different downscaling techniques (dynamic vs. statistical) adds to this complexity.

While the nuances in the climate literature may be familiar to climate scientists, they are more obtuse to many of the interviewees who often do not have training in the climate sciences and who may encounter research results as standalone information - e.g., in a presentation at a meeting, an abstract, or referenced in a publication-without the context 
that could be provided by a synthesis of information across studies. The findings of the climate studies cited above are complex, and without meaningful guidance as to how to interpret and use these products, practitioners we spoke with struggle to tease out the relevant findings and the impacts on an array of seasonal precipitation and wetland-related variables, particularly as they relate to the local climate knowledge canon discussed above (e.g., Johnson et al. 2005, 2010). Some impact studies have begun to discuss findings from different climate projections and the implications for wetland management in the PPR (e.g., Reese and Skagen 2017; Sofaer et al. 2016). These types of studies will be increasingly useful in the future, but require collaboration between the climate, biological, ecological science, and wildlife management communities.

\section{Policy and management processes as entry points}

Recurring management decisions and iterative policy revisions that are climate-sensitive (Ray and Webb 2016) offer opportunities for the climate science community to engage with the wildlife management community and ecological researchers, provide guidance regarding the selection and use of appropriate climate data, and synthesize the latest scientific findings. Opportunities include the climate vulnerability assessments conducted as part of evolving public policy processes, such as Endangered Species Act listing considerations, the SWAP revisions which take place every 10 years, or annual hunting license quotas. All five SWAPS analyzed cite the need for a better understanding of weather-climate-ecological relationships to inform species vulnerability assessments. Processes for siting conservation easements or oil and natural gas permitting is also an opportunity. Co-productive scenario planning could provide opportunities for iterative engagement between the wildlife management and climate science communities, help make management decisions under uncertainty, and link critical management issues of today with adaptation planning for the future (Fisichelli et al. 2016; Meadow et al. 2015; Murphy et al. 2016; Star et al. 2016). Increased engagement can also lead to a greater understanding of both the possibilities and limitations of the science and the types of management questions which are climate sensitive.

\section{Trusted sources as entry points}

Leveraging trusted sources to provide climate information can be useful in cases where co-production or interaction between the climate science community and information users is not feasible (Dilling and Berggren 2014; Dilling et al. 2015). Trusted sources include individuals, organizations, or sources of print and digital information. Here, we focus on two trusted online sources of weather information identified by interviewees that could serve as pathways for introducing climate information in the PPR: the USFWS Habitat and Population Evaluation Team (HAPET) and the North Dakota Agricultural Weather Network (NDAWN). HAPET (US Fish and Wildlife Service 2015, www.fws.gov/mountain-prairie/refuges/hapet. php) is part of the Migratory Bird Division of the USFWS and produces spatially-explicit information to support migratory bird management in the upper mid-west region of the USA. HAPET currently provides limited information about the impact of climate change on waterfowl habitat, which could be expanded. NDAWN (North Dakota State University 2018, ndawn.ndsu.nodak.edu) is a free service providing hourly weather data for 72 stations across ND which does not currently provide climate information. Interviewees reported routinely using weather data on NDAWN to inform their short-term management plans, for example, to inform decisions about prescribed burning to manage invasive plant species. Both HAPET and NDAWN could be platforms for the dissemination of climate information and serve to connect providers and users of climate change information.

\section{Conclusion}

We used interviews, policy document analysis of State Wildlife Action Plans, and participant observation to identify climate information needs for the wildlife management community in the PPR. We found that climate information needs are driven by questions about how projected changes in future precipitation and temperature will impact prairie wetland and grassland habitat and dependent species. Practitioners we spoke with need guidance in understanding, selecting, and applying available climate information, and they face both science-related and social barriers to integrating climate information into decisionmaking. These findings are consistent with the growing literature on climate information needs; however, our findings highlight the importance of putting new climate information or guidance in the context of actual ways that climate information is already being used and understood. This includes considering the nuanced ways that practitioners and researchers may use climate information to conduct their own exploratory analysis and the importance of the local climate knowledge canon in shaping regional understanding of the current climate and projected climate change. Additional research on the roles of natural resource managers and how they actually use climate information could help the climate science community better understand the decision-making context in which climate information could be used.

We recommend that guidance on using climate information could come in the form of a synthesis that describes the differences between available and updated GCMs, and 
between various downscaled products, that interpret what these differences might mean for applications of this information in ways that are accessible and understandable for the natural resource management community. Additional efforts are needed in the climate science community to engage with users of climate information to produce these guidance documents. Such a synthesis could be useful during recurring management decisions or policy updates, provided along with existing trusted sources of climate and weather information. Leveraging these existing policy processes or information sources can potentially increase engagement between the climate science and wildlife management communities and reduce costs associated with using climate information to inform decision-making.

Our work points to the importance of identifying the particular social and ecological aspects of the decision-making context. These contexts will shape what useful information will look like for those particular sectors, regions, or users. Understanding this decision-making context and how climate information fits into complex social and ecological systems will require increased engagement between the climate science and management communities, and continued interdisciplinary work on climate change impacts and adaptation. Additional research is needed on how particular sources of climate information become part of the local climate knowledge canon, and to what extent this canon facilitates or prevents the incorporation of new climate information into institutional decisionmaking practices in the wildlife management and other sectors. These insights will contribute to increasing the usability of climate and weather information for practitioners and researchers in the PPR and for other sectors and regions.

Acknowledgements We are very grateful to people in the PPR who took time to speak with us and who opened their meetings to us. Without their insights, this research would not have been possible. We also thank Richard Nelson for his observations and feedback which provided depth and context for this study, Joseph Barsugli for his thoughtful comments, and the editors and anonymous reviewers for their comments and insights which greatly improved this manuscript.

Funding information This study was funded by the National Science Foundation (award \# 1243270) and the NOAA/ESRL Physical Sciences Division.

\section{Compliance with ethical standards}

The participation of human subjects in this study was approved by the University of Colorado Internal Review Board.

Conflict of interest The authors declare that they have no conflict of interest.

Open Access This article is distributed under the terms of the Creative Commons Attribution 4.0 International License (http:// creativecommons.org/licenses/by/4.0/), which permits unrestricted use, distribution, and reproduction in any medium, provided you give appropriate credit to the original author(s) and the source, provide a link to the Creative Commons license, and indicate if changes were made.

Publisher's note Springer Nature remains neutral with regard to jurisdictional claims in published maps and institutional affiliations.

\section{References}

Archie KM, Dilling L, Milford JB, Pampel FC (2012) Climate change and western public lands: a survey of U.S. federal land managers on the status of adaptation efforts. Ecol Soc 17(4). https://doi.org/10. 5751/ES-05187-170420

Association of Fish and Wildlife Agencies (2012) Best practices for state wildlife action plans: voluntary guidance to states for revision and implementation. Association of Fish and Wildlife Agencies, Washington, D.C http://www.fishwildlife.org/files/ SWAPBestPractices.pdf

Ballard T, Seager R, Smerdon JE, Cook BI, Ray AJ, Rajagopalan B, Kushnir Y, Nakamura J, Henderson N (2014) Hydroclimate variability and change in the prairie pothole region, the 'duck factory' of North America. Earth Interact 18(14):1-28. https://doi.org/10.1175/ EI-D-14-0004.1

Barsugli J, Anderson C, Smith JB, Vogel JM (2009) Options for improving climate modeling to assist water utility planning for climate change. Water Utility Climate Alliance White Paper. Water Utility Climate Alliance, San Francisco

Barsugli J, Vogel J, Kaatz L, Smith J, Waage M, Anderson C (2012) Two faces of uncertainty: climate science and water utility planning methods. J Water Resour Plan Manag 138(5):389-395. https://doi. org/10.1061/(ASCE)WR.1943-5452.0000188

Beeri O, Phillips RL (2007) Tracking palustrine water seasonal and annual variability in agricultural wetland landscapes using Landsat from 1997 to 2005. Glob Chang Biol 13(4):897-912. https://doi. org/10.1111/j.1365-2486.2006.01306.x

Berggren J (2012) Western water assessment report: analysis of documented stakeholder needs for climate information in the Missouri River basin. National Oceanic and Atmospheric Administration, Boulder http://wwa.colorado.edu/publications/reports/missouri basin_final_report.pdf

Bernard RH (2005) Research methods in anthropology: qualitative and quantitative approaches, 4 th edn. Altamira Press, New York

Bickman L, Rog DJ (eds) (2009) The SAGE handbook of applied social research methods, 2nd edn. Sage, Los Angeles

Blodgett DL, Booth NE, Kunicki TC, Walker JI, Viger RJ (2011) Description and testing of the geo data portal: data integration framework and web processing services for environmental science collaboration. No. 2011-1157. US Geological Survey https://pubs.usgs. gov/of/2011/1157/

Briley L, Brown D, Kalafatis SE (2015) Overcoming barriers during the co-production of climate information for decision-making. Climate Risk Manag 9:41-49. https://doi.org/10.1016/j.crm.2015.04.004

Bureau of Reclamation (2013) Downscaled CMIP3 and CMIP5 climate and hydrology projections: release of downscaled CMIP5 climate projections, comparison with preceding information, and summary of user needs. Denver, Colorado. http://gdo-dcp.ucllnl.org/ downscaled_cmip_projections/techmemo/downscaled_climate.pdf

Cash DW, Clark W, Alcock F, Dickson N, Eckley N, Jager J (2002) Salience, credibility, legitimacy and boundaries: linking research, assessment and decision making. John F. Kennedy School of Government, Harvard University, Cambridge http://papers.ssrn.com/sol3/papers.cfm?abstract id $=372280$ 
Ciuti S, Jensen WF, Nielsen SE, Boyce MS (2014) An evaluation of historical mule deer fawn recruitment in North Dakota. North Dakota Game and Fish Department, Bismarck ND, Bismarck https://gf.nd.gov/node/1759

Ciuti S, Jensen WF, Nielsen SE, Boyce MS (2015) Predicting mule deer recruitment from climate oscillations for harvest management on the northern Great Plains. J Wildl Manag 79(8):1226-1238. https://doi. org/10.1002/jwmg.956

Cook BI, Benjamin I, Smerdon JE, Seager R, Coats S (2014) Global warming and 21st century drying. Clim Dyn 43(9-10):2607-2627. https://doi.org/10.1007/s00382-014-2075-y

DeWalt KM, DeWalt BR (2002) Participant observation: a guide for fieldworkers. Rowman Altamira, Walnut Creek

Dilling L, Berggren J (2014) What do stakeholders need to manage for climate change and variability? A document-based analysis from three mountain states in the Western USA. Reg Environ Chang 15(4):657-667. https://doi.org/10.1007/s10113-014-0668-y

Dilling L, Lackstrom K, Haywood B, Dow K, Lemos MC, Berggren J, Kalafatis S (2015) What stakeholder needs tell us about enabling adaptive capacity: the intersection of context and information provision across regions in the United States. Weather Climate Soc 7(1):5-17. https://doi.org/10.1175/WCAS-D-14-00001.1

Doherty KE, Ryba A, Stemler CL, Niemuth ND, Meeks WA (2013) Conservation planning in an era of change: state of the U.S. prairie pothole region. Wildl Soc Bull 37(3):546-563. https://doi.org/10. 1002/wsb. 284

Dyke S, Johnson S, Isakson P (2015) North Dakota state wildlife action plan 2015. North Dakota Department of Game and Fish, Bismarck https://gf.nd.gov/sites/default/files/publications/swap-2015.pdf

Ellenwood M, Dilling L, Milford JB (2012) Managing United States public lands in response to climate change: a view from the ground up. Environ Manag 49(5):954-967. https://doi.org/10.1007/s00267012-9829-2

Fisichelli N, Schuurman G, Symstad A, Ray AJ, Miller B, Cross M, Rowland E (2016) Resource management and operations in southwest South Dakota: climate change scenario planning workshop summary January 20-21, 2016, Rapid City, SD. Natural resource report NPS/NRSS/NRR - 2016/1289. National Park Service, Fort Collins, Colorado. https://pubs.er.usgs.gov/publication/70176347

Glick P, Stein BA, Edelson N (2011) Scanning the conservation horizon: a guide to climate change vulnerability assessment. National Wildlife Federation, Washington, DC http://www.nwf.org/ /media/ pdfs/global-warming/climate-smart-conservation/ nwfscanningtheconservationhorizonfinal92311.ashx

Gonzalez P (2011) Science for natural resource management under climate change. Issues Sci Technol 27(4):65-74

Habitat and Population Evaluation Team (HAPET). US Fish and Wildlife Service Migratory Bird Division, August 7, 2015. www.fws.gov/ mountain-prairie/refuges/hapet.php. April 12, 2018

Heller NE, Zavaleta ES (2009) Biodiversity management in the face of climate change: a review of 22 years of recommendations. Biol Conserv 142(1):14-32. https://doi.org/10.1016/j. biocon.2008.10.006

Iowa Department of Natural Resources (2015) Iowa's wildlife action plan: securing a future for Fish and wildlife. Iowa Department of Natural Resources, Des Moines http://www.iowadnr.gov/ Conservation/Wildlife-Stewardship/Iowa-Wildlife-Action-Plan

IPCC (2010) AR5: chapter 9.6: downscaling and simulation of regionalscale climate. Cambridge University Press, New York https://www. ipcc.ch/pdf/assessment-report/ar5/wg1/WG1AR5_Chapter09_ FINAL.pdf

Jantarasami LC, Lawler JJ, Thomas CW (2010) Institutional barriers to climate change adaptation in U.S. national parks and forests. Ecol Soc 15(4):1-16

Johnson WC, Boettcher SE, Poiani KA, Guntenspergen GR (2004) Influences of weather extremes on the hydrology of glaciated prairie wetlands. Wetlands 24(2):385-398. https://doi.org/10.1672/02775212(2004)024[0385:IOWEOT]2.0.CO;2

Johnson WC, Millett BV, Gilmanov T, Voldseth RA, Guntenspergen GR, Naugle DE (2005) Vulnerability of northern prairie wetlands to climate change. BioScience 55(10):863-872. https://doi.org/10.1641/ 0006-3568(2005)055[0863:VONPWT]2.0.CO;2

Johnson WC, Werner B, Guntenspergen GR, Voldseth RA, Millett B, Naugle DE, Tulbure M, Carroll RWH, Tracy J, Olawsky C (2010) Prairie wetland complexes as landscape functional units in a changing climate. BioScience 60(2):128-140. https://doi.org/10.1525/bio. 2010.60.2.7

Kemp KB, Blades JJ, Klos PZ, Hall TE, Force JE, Morgan P, Tinkham WT (2015) Managing for climate change on federal lands of the western United States: perceived usefulness of climate science, effectiveness of adaptation strategies, and barriers to implementation. Ecol Soc 20(2). https://doi.org/10.5751/ES-07522-200217

Knutti R, Sedláček J (2013) Robustness and uncertainties in the new CMIP5 climate model projections. Nat Clim Chang 3(4):369-373. https://doi.org/10.1038/nclimate1716

Kunkel KE, Stevens LE, Stevens SE, Sun L, Janssen E, Wuebbles D, Kruk MC, Thomas DP, Shulski MD, Umphlett NA, Hubbard KG, Robbins K, Romolo L, Akyuz A, Pathak TB, Bergantino TR, Dobson JG (2013) NOAA Technical report NESDIS 142-4: Regional climate trends and scenarios for the U.S. National Climate Assessment, Part 4. Climate of the U.S. Great Plains. National Oceanic and Atmospheric Administration, Washington, DC http://scenarios.globalchange.gov/sites/default/files/NOAA NESDIS_Tech_Report_142-4-Climate_of_the_U.S.\%20Great Plains_0. pdf

Lawler JJ, Shafer SL, White D, Kareiva P, Maurer EP, Blaustein AR, Bartlein PJ (2009) Projected climate-induced faunal change in the western hemisphere. Ecology 90(3):588-597. https://doi.org/10. 1890/08-0823.1

Lemieux C, Thompson JL, Dawson J, Schuster RM (2013) Natural resource manager perceptions of agency performance on climate change. J Environ Manag 114:178-189. https://doi.org/10.1016/j. jenvman.2012.09.014

Lemos MC, Kirchhoff CJ, Ramprasad V (2012) Narrowing the climate information usability gap. Nat Clim Chang 2(11):789-794. https:// doi.org/10.1038/nclimate1614

Maurer EP, Brekke L, Pruitt T, Thrasher B, Long J, Duffy P, Dettinger M, Cayan D, Arnold J (2014) An enhanced archive facilitating climate impacts and adaptation analysis. Bull Am Meteorol Soc 95(7): 1011-1019. https://doi.org/10.1175/BAMS-D-13-00126.1

Mawdsley JR, O’Malley R, Ojima DS (2009) A review of climate-change adaptation strategies for wildlife management and biodiversity conservation. Conserv Biol 23(5):1080-1089. https://doi.org/10.1111/j. 1523-1739.2009.01264.x

Meadow AM, Ferguson D, Guido Z, Horangic A, Owen G, Wall T (2015) Moving toward the deliberate coproduction of climate science knowledge. Weather Climate Soc 7(2):179-191. https://doi.org/10. 1175/WCAS-D-14-00050.1

Millett B, Johnson WC, Guntenspergen G (2009) Climate trends of the north American prairie pothole region 1906-2000. Clim Chang 93(1-2):243-267. https://doi.org/10.1007/s10584-008-9543-5

Minnesota Department of Natural Resources (2016) Minnesota's wildlife action plan 2015-2025. Division of ecological and water resources. Minnesota Department of Natural Resources, St. Paul http://files. dnr.state.mn.us/assistance/nrplanning/bigpicture/mnwap/wildlifeaction-plan-2015-2025.pdf

Montana Fish, Wildlife, and Parks (2015) Montana's state wildlife action plan. Montana Fish, Wildlife, and Parks, Helena, MT http://fwp.mt. gov/fishAndWildlife/conservationInAction/swap2015Plan.html

Murphy D, Wyborn C, Yung L, Williams DR, Cleveland C, Eby L, Dobrowski S, Towler E (2016) Engaging communities and climate change futures with multi-scale, iterative scenario building (MISB) 
in the Western United States. Hum Organ 75(1):33-46. https://doi. org/10.17730/0018-7259-75.1.33

National Climate Assessment (2010) Report Series, Volume 7, Chapter 2.7.1: Right-Scaling Climate Models. In Climate Change Modeling and Downscaling: Issues and Methodological Perspectives for the U.S. National Climate Assessment. Arlington, VA. https://downloads.globalchange.gov/nca/workshop-reports/ Modeling\%20and\%20Downscaling FINAL.pdf

NatureServe Climate Change Vulnerability Index. NatureServe. www. natureserve.org/conservation-tools/climate-change-vulnerabilityindex. April 12, 2018

Niemuth ND, Fleming KK, Reynolds RE (2014) Waterfowl conservation in the US prairie pothole region: confronting the complexities of climate change. PLoS ONE 9(6):e100034. https://doi.org/10.1371/ journal.pone. 0100034

NOAA GFDL (2018) National Oceanic and Atmospheric Administration Geophysical Fluid Dynamic Laboratory website, Climate Model Downscaling. https://www.gfdl.noaa.gov/climate-modeldownscaling/

North Dakota Agricultural Weather Network (NDAWN). North Dakota State University. ndawn.ndsu.nodak.edu. April 12, 2018

Olliff ST, Hansen AJ (2016) Challenges and approaches for integrating climate science into federal land management. In: Hansen A, Monahan W, Thoebald D, Olliff A, Monahan W, Theobald D, Olliff ST (eds) Climate Change in Wildlands. Island Press, Boca Raton, pp 33-52. https://doi.org/10.5822/978-1-61091-713-1 3

Ostergren JD (2003) SWANCC in duck country: will court-ordered devolution fill the prairie potholes? Stanford Environ Law J 22(2): 381-443

Rashford BS, Walker JA, Bastian CT (2011) Economics of grassland conversion to cropland in the prairie pothole region. Conserv Biol 25(2):276-284. https://doi.org/10.1111/j.1523-1739.2010.01618.x

Ray AJ, Webb RS (2016) Understanding the user context: decision calendars as frameworks for linking climate to policy, planning and decision-making. In: Parris A, Garfin GM, Dow K, Meyer R, Close SL (eds) Climate in context: science and society partnering for adaptation. Wiley \& Sons Ltd, Chichester, pp 27-50

Ray AJ, Barsugli J, Ojima DO, Symstad AJ, Sofaer H, Perry L, Bachelet D, Post van der Burg M, Sojda R, Morisette J (2018) The logic of collaboration: improving climate-ecological vulnerability assessment in the north central US. Submitted to Global Change Biology

Reese GC, Skagen SK (2017) Modeling nonbreeding distributions of shorebirds and waterfowl in response to climate change. Ecol Evol 7(5):1497-1513. https://doi.org/10.1002/ece3.2755

Reinharz S (1992) Feminist methods in social research. Oxford University Press, New York

Reynolds RE, Shaffer TL, Renner RW, Newton WE, Batt BDJ (2001) Impact of the conservation reserve program on duck recruitment in the U.S. prairie pothole region. J Wildl Manag 65(4):765-780. https://doi.org/10.2307/3803027

Shafer M, Ojima DS, Antle JM, Kluck D, McPherson RA, Petersen S, Scanlon B, Sherman K (2014) Ch. 19: Great Plains. In: Melillo J, Richmond TC, Yohe GW (eds) Climate change impacts in the United States: the third National Climate Assessment, U.S. global change research program: Washington, D.C. http://nca2014. globalchange.gov/downloads

Snover A, Mantua NJ, Littell JS, Alexander MA, McClure MM, Nye J (2013) Choosing and using climate-change scenarios for ecologicalimpact assessments and conservation decisions. Conserv Biol 27(6): 1147-1157. https://doi.org/10.1111/cobi.12163
Sofaer HR, Skagen SK, Barsugli JJ, Rashford BS, Reese GC, Hoeting JA, Wood AW, Noon BR (2016) Projected wetland densities under climate change: habitat loss but little geographic shift in conservation strategy. Ecol Appl 26(6): 1677-1692. https://doi.org/10.1890/15-0750.1

South Dakota Department of Game, Fish and Parks (2014) South Dakota wildlife action plan. South Dakota Department of Game, Fish and Parks, Rapid City http:/gfp.sd.gov/images/WebMaps/Viewer/WAP/ Website/PlanSections/SD\%20Wildlife\%20Action\%20Plan\% 20Revision\%20Final.pdf

Star J, Rowland EL, Black ME, Enquist CAF, Garfin G, Hoffman CH, Hartmann H, Jacobs KL, Moss RH, Waple AM (2016) Supporting adaptation decisions through scenario planning: enabling the effective use of multiple methods. Clim Risk Manag 13(January):88-94. https://doi.org/10.1016/j.crm.2016.08.001

Stein BA, Glick P, Edelson N, Staudt A (2014) Climate-smart conservation: putting adaptation principles into practice. National Wildlife Federation, Washington, D.C. www.nwf.org/ /media/PDFs/ Global-Warming/Climate-Smart-Conservation/NWF-ClimateSmart-Conservation 5-08-14.pdf

Theoharides K, Barnhart G, Glick P (2009) Climate change adaptation across the landscape: a survey of federal and state agencies, conservation organizations and academic institutions in the United States. The Association of Fish and Wildlife Agencies, Merrifield http:// www.defenders.org/publications/climate_change_adaptation across_the_landscape.pdf

Trzaska S, Schnarr E (2014) A review of downscaling methods for climate change. US Agency for International Development, Washington, DC http://www.ciesin.org/documents/Downscaling CLEARED 000.pdf

Waylen K, Blackstock K, Holstead K (2015) How does legacy create sticking points for environmental management? Insights from challenges to implementation of the ecosystem approach. Ecol Soc 20(2). https://doi.org/10.5751/ES-07594-200221

West JM, Julius SH, Kareiva P, Enquist C, Lawler JJ, Petersen B, Johnson AE, Shaw MR (2009) U.S. natural resources and climate change: concepts and approaches for management adaptation. Environ Manag 44(6):1001-1021. https://doi.org/10.1007/s00267-0099345-1

Wilby RL, Dessai S (2010) Robust adaptation to climate change. Weather 65(7):180-185. https://doi.org/10.1002/wea.543

Wilby RL, Charles SP, Zorita E, Timabl B, Whetton P, Mearns LO (2004) Guidelines for uSe of climate scenarios developed from statistical downscaling methods. IPCC. http://www.ipcc-data.org/guidelines/ dgm_no2_v1_09_2004.pdf

Winter TC, Rosenberry DO (1998) Hydrology of prairie pothole wetlands during drought and deluge: a 17-year study of the cottonwood Lake wetland complex in North Dakota in the perspective of longer term measured and proxy hydrological records. Clim Chang 40(2):189 209. https://doi.org/10.1023/A:100544841657

Wootten A, Smith K, Boyles R, Terando A, Stefanova L, Misra V, Smith T, Blodgett D, Semazzi F (2014) Downscaled climate projections for the Southeast United States: evaluation and use for ecological applications. USGS southeast climate science center, Raleigh, NC. https://pubs.usgs.gov/of/2014/1190/

Yocum HM (2017) Land and wildlife managers' use of climate information in the prairie potholes region. Adaptation Working Group Webinar. http://nccsc.colostate.edu/event/4-11-2017/adaptationworking-group-webinar 